artige Wirkung hat oder nicht und festgestellt, dass ihm diese Wirkung zukommt.

Ich habe nämlich aus $1 \mathrm{~g}$ Moschus dessen Methanolextrakt hergestellt, denselben. mittels Olivenoel auf $10 \mathrm{ccm}$ gebracht und $0,2 \mathrm{cc} \mathrm{d}$. h. eine Dosis, die $20 \mathrm{mg}$ Moschus entspricht, nur einmal zur Bepinselung des Kapaunenkamms angewandet und vom naechsten Tage an täglich einmal die Groesse des Hahnenkamms gemessen. Was diese Messung anbetrifft, so handelt es sich um die Feststellung des Produkts aus Länge und Höhe und die folgende Tabelle gibt den Prozentsatz seiner Vergroesserung.

\begin{tabular}{c|c|c|c|c|c|c|c|c|c}
\hline $\begin{array}{c}\text { Kapaun } \\
\text { Nr }\end{array}$ & 1. Tag & 2. Tag & 3. Tag & 4. Tag & 5. Tag & 6. Tag & 7. Tag & 8. Tag & 9. Tag \\
\hline Nr. 5 & 0 & 8,7 & 17,8 & 13,4 & 13,4 & 6,6 & 4,3 & 4,3 & \\
Nr. 4 & 0 & 18,0 & 31,8 & 33,3 & 27,9 & 25,7 & 23,7 & 19,8 & 13,9 \\
Nr. 81 & 0 & 7,0 & 21,8 & 17,9 & 17,9 & 10,5 & 10,5 & 4,0 & \\
Nr. 10 & 0 & 6,0 & 19,0 & 30,9 & 23,1 & 15,4 & 9,9 & 8,0 &
\end{tabular}

Die folgende Tabelle gibt die Resultate der Bepinselung mit 0,2 cc einer Olivenoelloesung an, in der nach derselben Methode $100 \gamma$ trans-Dehydroandrosteron geloest worden sind.

\begin{tabular}{c|c|c|c|c|c|c}
\hline $\begin{array}{c}\text { Kapaun } \\
\text { Nr. }\end{array}$ & 1. Tag & 2. Tag & 3. Tag & 4. Tag & 5. Tag & 6. Tag \\
\hline Nr. 41 & 0 & 12,8 & 19,0 & 24,1 & 27,4 & 20,7 \\
Nr. 3 & 0 & 10,6 & 18,0 & 16,0 & 12,4 & 10,6
\end{tabular}

Man sieht hieraus, dass nach dieser Methode $100 \gamma$ trans-Dehydroandrosteron mit $20 \mathrm{mg}$ Moschus fast aehnliche Resultate geben. Versuche sind momentan im Gange, um festzustellen, ob der Moschus auf den Samenblase wirkt oder nicht und er ob die weiblich brunsthormonartigen Wirkung hat oder nicht.

\title{
Ueber die pharmakognostische Untersuchung der Droge "Hikai."
}

$$
\text { von }
$$

\section{N. Fujita und T. Harada}

[Aus dem pharmazeutischen Institut der Kaiserlichen Universität zu Tokyo]

(Eingegangen am 18. Oktober 1936.)

Die Droge "Hikai" stammt aus Dioscorea Tokoro Makino. Sie vermischt sich manchmal mit anderen Dioscorea-Arten, die liegende Wurzelstöcke besitzen, da beide 
im Walde vermischt mit einander wachsen; jedoch kann man sie nach ihrem Aussehen oder mikroskopisch von einander unterscheiden.

Die Wurzelstöcke von D. Tokoro (Fig. 1) und von D. tenuipes Franch. et Sav. (Fig. 5: A) sind mikroskopisch gleich, und das Parenchym der Grundgewebe dieser beiden Arten besteht aus Zellulose, das der Wurzelstöcke der anderen 5 Arten zeigt aber Holzreaktion. Bei $D$. tenuipes sind die Internodien des Wurzelstockes $1 \mathrm{~cm}$ lang und viel verzweigt; bei $D$. Tokoro sind dieselben $4 \mathrm{~cm}$ lang und selten verzweigt. In der Querschnittfläche sind Gefässbündel zerstreut bei der letzteren vorhanden, bei der vorerwähnten sind dagegen die Gefässbündel meist in einigen kleinen kreisen angeordnet (Fig. 5: B). Bei dem Wurzelstocke von D. gracillima Miq. (Fig. 6) liegen die Stengelnarben am kurzen $Z$ weig; bei D. septemloba Thunb. (Fig. $10:$ A) befinden sich aber die Stengelnarben am Wurzelstock vertieft. Die Korkschicht der ersteren besteht aus zahlreicheren und dickwandigeren Zellen als die der letzteren. Der Wurzelstock von D. nipponica Makino (Fig. 13: A) ist sehr lang und durch Trocknen längsweise gleichlaufend gefaltet. Er wird auch durch das Vorhandensein der Haare und Querbalkenzellen (Fig. 14) in der dünnwandigen Korkschicht von demjenigen von D. Tokoro unterschieden; zudem kann man ihn durch das Unverholztbleiben einiger zellschichtiger Parenchyme in der Peripherie von $D$. septemloha unterscheiden. Das Rhizom von D. quinqueloba Thunb. (Fig. 12: A) kann man durch die groben Runzeln und die grossen isodiametrischen dickwandigen Korkzellen unterscheiden. Die Endodermis fehlt, und die Saponinreaktion ist positiv bei allen Arten.

Wir konnten die Rhizome von $D$. Tokoro, D. gracillima und $D$. nipponica in einer Handelsware finden; ausserdem werden die kugelförmigen Knollen von D. bulbifera L, f. spontanea (Makino) (Fig. 17 : A, B) zuweilen als "Hikai" verkauft.

\section{Erklärungen der Abbildungen. (vgl. jap. Text)}

Fig. 1. Dioscorea T'okoro, Drogen $\times 2 / 3$.

Fig. 2. " , , Lupenbilder der Querschnitte.

Fig. 3. " ", Querschnitt.

Fig. 4. " " , Lüngsschnitt u. Zelleinschlüsse.

Fig. 5. D. tenuipes, A : Drogen $\times 2 / 3$, B : Lupenbild des Querschnitts.

Fig. 6. D. gracillima, Drogen $\times 2 / 3$.

Fig. 7. " " , Lupenbild des Querschnitts.

Fig. 8. " " , Querschnitt.

Fig. 9. " " , Längsschnitt u. Stärkekörner. 
Fig. 10, D. septemloba, A: Droge $\times 2 / 3$, B ; Lupenbild des Querschnitts,

Fig. 11. A : Querschnitt von D. septemloba, B: Querschnitt von D. quinqueloba.

Fig. 12. D. quinqueloba, A : Droge $\times 2 / 3$, B : Lupenbild des Querschnitts.

Fig. 13. D. nipponica, A : Droge $\times 2 / 3$, B : Lupenbild des Querschnitts.

Fig. 14. , ", Querschnitt.

Fig. 15. " , , Haare am Rhizom.

Fig. 16. " " , Längsschnitt.

Fig. 17. D. bulbifera f. spontanea, Drogen $\times 2 / 3$.

Fig. 18. " " , ", Querschnitt.

Fig. 19. " " " , , A : Parenchym, B : Gefässe, C : Stärkekörner.

$C u t$ : Cuticula, Ep: Epidermis, Es: Erdspross, F: Faser, Gbs: Gefässbündelscheide, Gel: Geleitzelle $G f b$ : Gefässbündel, $G g$ : Grundgewebe, Grb : Gerbstoff, $H$ : Haar, Hgf: Hoftüpfelgefïss, Hp : Holzparenchym, Htr: Hoftüpfeltracheide, $K$ : dünwandige Korzelle, $K^{\prime}$ : dickwandige Korkzelle, $K r$ : Raphidenbündel von Ca-Oxalat, $K s$ : Korkschicht, $N g f$ : Netzgefäss, $O t$ : Oeltropfen, $Q b$ : Querbalken, Rgf: Ringgefisss, $S$ : Siebröhren, Sch: Schleim, Sgf: Spiralgefäss, Spl: Siebplatte, Sta: Stärkekörner, Stg: Stengel, Trg: Treppengefäss, $W$ : Wurzel. 


\title{
日本産草薢の生藥學的研究
}

\author{
藤田直市 \\ 原田利一
}

（東大醫學部藥學科生藥學呚室）

（昭和 11 年 10 月 18 日受理）

N. Fujita u. T. Harada ; Ueber die pharmakognostische

Untersuchung der Droge „Hikai“.

總論

草蔽は古來使朋せらるる和漢藥の一にして, 本草利名（900 年頃）以來の我國本草壸, 皆ヤ マノイモ科 (Dioscoreaceae) のオニドコロ(一名トコロ) Dioscorea Tokoro Makino 原植物と して收錄し，その後ヤマノイモ屬 (Dioscorea sp.) の他の數品を当件朋するに至れり。郎ち本草

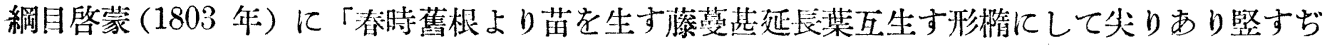
のみにして山藥葉の如くにして大なり根も亦山藥に似たり蒸煮て食へばオニドコロより柔にし て味甘く微く黄し是川草薢なり本䌡逢原日産川中大塊色白而鬆脆者䉆草薢一種オニドコロあり

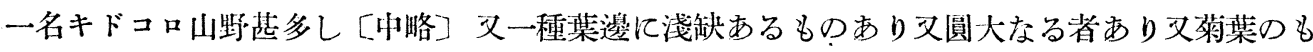
のありその餘品類多しょと, 又岩崎常正は本草圖譜 (1828 年) 第 25 叁の草薢の目に, ヤマ> イモ屬の蒙草 5 種を登載したり，份ほ又草木圖說（1832 年）に於いては山草薢にオニドコロ を, 川草薢にニガガシュウを充當したり。

著者等はニガガシュウ Dioscorea bulbifera L. f. spontanea (Makino), タチドコロ D. gracillima Miq., ウチハドコロ D. nipponica Makino, カヘデドコロ D. quinqueloba Thunb., キ クバドコロ D. septemloba Thunb., ヒメドコロ D. tenuipes Franch. et Sav., オニドコロ $D$. Tokoro Makinoの 7 者を剖見し，沙場品と比較して，その據る所を明かにするを得たり。

其結論を概括すれば, オニドコロとヒメドコロの根葬は, 內部構造にては制然たる區別困難 にして外形に依り識別するを可とす, 即ちヒメドコロは外面赤褐色乃至黑褐色を呈し, 㿲紋を 有し，精粗種をなる淺き縱皱を現し節閒短く略 $1 \mathrm{~cm}$ 内外にして分岐多きを常とすれども，オ ニドコロは節間長く $4 \mathrm{~cm}$ に至り分岐する事稀なり, 义その橫截面をルーぺにて檢すればオ二 ドコロは脈管束が點在するに對し，ヒメドコロは多くは 1 乃至數简の小圈輸をなす，又其味オ ニドコロはヒメドコロより遥に苦し. 佾ほての兩者の乘細胞は其にツェルローゼ反應を呈すれど も, 他の 5 者の夫れは膜壁稍木化し孔斑明膫なり.タチドコロとキクバドコロとは, 前者は地上 


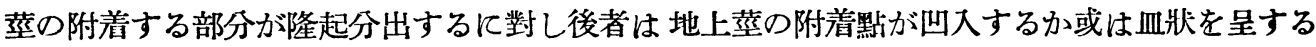
以外は, 根懂の外觀酷似すれども, 顯微鏡的に, 前者の厚壁性枹首は後者の夫れに 比して多首 且つ厚膜なる事に依りて容易に區别せらる. ウチハドコロは甚だ長き根莖を有するものなれぼ, 其の短く切斷せるものはオニドュロと稍類似するも, その表面には略平行せる長き縱触存在し, 顯微鏡的構造に於いては毛茸を有し，横梁細胞が薄壁性枹層中に混在する事に依りオニドコロと 容易に區別せられ，又內部構造上稍類似せるキクバドコロとは前記毛苗竝びに橫梁を有する事 及實體組織の外邊に存在する數愿の柔細胞はその膜壁が水化せざる事に依り判然と區別せらる. カへデドコロはその形狀，構造が稍タチドコロ,キクバドコロに類似すと雖も,外形的にはその 粗大なる媰に依り，又內部構造上は厚膜性枹細胞が大形且つ略等徑性なる事に依り識別せらる. ニガガシュウはその形狀が塊狀にして, 更に內部構造的には網目樣の膜質ありて澱粉粒を包圍 する等の差異を以つて，他の 6 者と確然と辨別せらる．侣活本屬が單子葉類に屬するに拘らず， 一般單子葉植物の根蕪に 比較し解剖上稍特異なるは, 7 者共薄壁性枹畨の內方に更に厚壁性枹 層を存する事，內上皮を認めざる事等なり．有效成分なるサポニンの反應は 7 者共に陽性なり， 而して現今才場品中には, オニドコロ, タチドコロ, ウチハドコロの根蕪に形狀站びに構造全 く一致するもの混在するを知れり，又稀にニガガシュウの塊蕉も販賣せらる.

此機に於いて種及御䡈示を賜りをる牧野富太郎先生, 站びに材料を惠與せられたる緒方正資, 岸田松若, 山岸晃, 藤田路一の誚氏に深甚の謝意を表す。

草蔮及オニドコロ Dioscorea Tokoro Makino

材料は束京市場に於ける生藥草䌜, 站びに祜奈川縣の諸處, 群馬縣伊香保, 同縣谷川岳山麓, 靜岡縣熱海, 同縣湯ケ島, 鹿兒島市及び櫻島にて自ら探集せる根菜の乾燥品站びにホルマリン 液浸標本に低れり。

形狀 生藥草薢 (Fig. 1) は通常長さ約 3-9 cm 徑 0.4-1.4 cm にして, 殆んど圓筒狀をな し分枝せるものあり，外面は淡黄褐色又は黄褐色にして，細大深淺種々なる縱溝を有し稀に横 裂を表す．諸處に小圓盤存在し，中央に黄褐色の突起あり，之䰅根の殘痕 (Fig. 1:W) 亿して 燒却せるため其長さ通常約 $1 \mathrm{~cm}$ なれども, 往々約 $10 \mathrm{~cm}$ 几至る事あり, 何れも外部は剩離し 內部のみ殘存し黃褐色を呈す，又處々に稍大なる淡黄色の小血狀をなせる地上苇の瘕痕 (Fig.

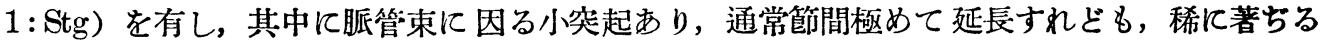
しく短縮せるもの存在す。土芽(Fig. $1:$ Es) は不規則且つ細微なる㖪を具有す，質硬く，破折 し易し．破折面は赤褐色，緻密にして稍凹凸を表す。香氣を有せず，之を噙めば稍粘液性にし て龁苦なり.

·構造 ルーペを以つて橫断面を覞ふに, 外周には菲薄にして黄褐色を呈する枹㕌(Fig. $2: \mathrm{Ks})$ ありて膨大なる實體組織(Fig. $2: \mathrm{Gg}$ )を圍む，實體組織中には帶鱼褐色の點として脈管束(Fig. 
2:Gfb）の不規則に散在するを認む．該脈管束は縱斷面にて根莖長軸の方向に殆んど本行せる ため, 橫斷面にては, 唯分枝部, 地上蒙 (Fig. 2:Stg) 及根 (Fig. 2:W) の分出點に於いて科縱

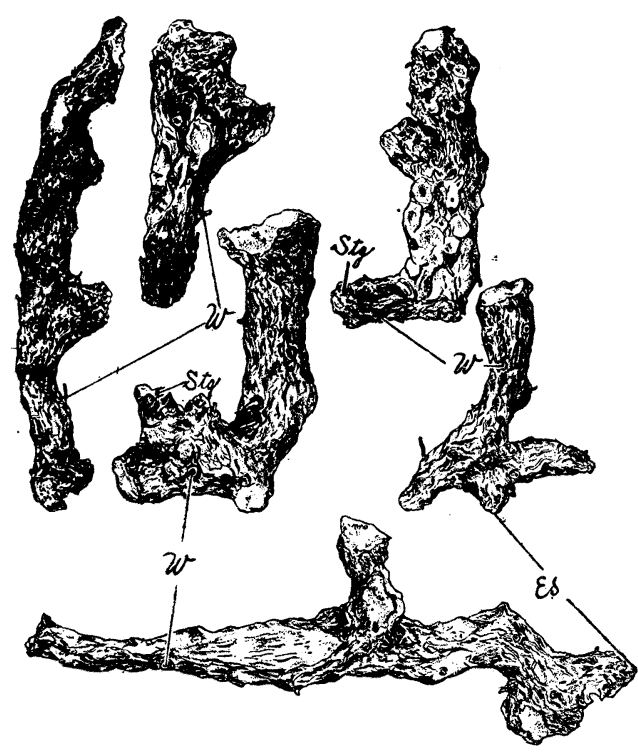

Fig. 1. オニドュロを原植物々せる书埸品の全形圆 $\times 2 / 3$. 斷面として現るるのみにして，その周圍は稍 暗褐色なり。

顯微鏡を以つて檢するに, 上皮(Fig. 3:Ep) は通常利離すれども稀に殘存し, 其の各細胞 は著しく橫徑に延長し，四圍の膜壁は殆んぎ 厚さを等しくしズダン III にて染色し, 其兩

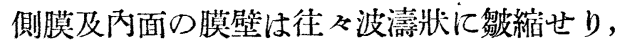
而して外層には强き枹化反應を呈する表皮膜 (Fig. 3: Cut) 存在す.上皮下には略等徑性に して不整且不規則に配列せる 2-4 層の淡黄 褐色の枹細胞より成る薄壁多角性枹層 (Fig. $3: \mathrm{K})$ あり, 其膜壁は非薄にしで, 枹化反應 を呈すれども木化反應を表さす。，乙次次ぐ厚 壁性枹層 (Fig. $3: \mathrm{K}^{\prime}$ ) は 2-8 層の大小形狀 を異にし，且つ代徑性方向に稍規則正しく配列せる枹細胞を以つて構成せられ，乙の膜壁は淡 资色にして厚く，孔斑老具佮す，水化反應站びに枹化反應は共に 初生膜層に於いて特に强し. 實體組織の柔細胞にして，外 邊のものは秒橫徑に延長せる も, 內部に至るに從ひ淵次等 徑性の柔組織に移行す，其膜 壁稍厚つく孔斑を具有すれど も木化反應を呈せず．然れど も極めて稀に 單獨又は $2-3$ 筐集合せる石核細胞嵌在す,

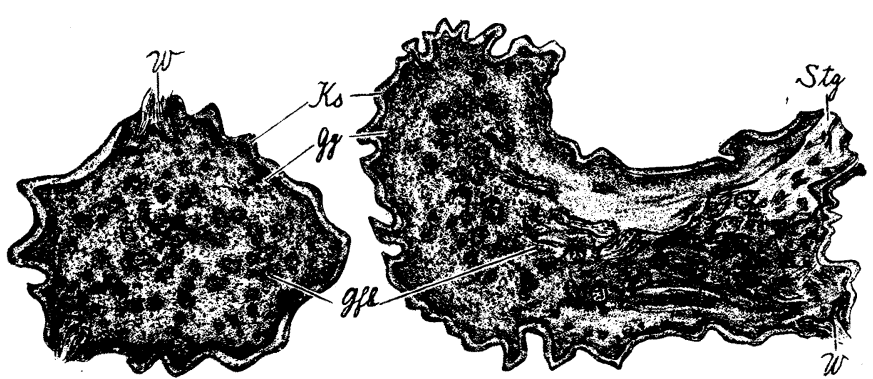

Fig. 2. オニドュロを原植物とせる古場品の横唁面ルーペ圆.

脈管束 (Fig. 3:B,C, D, E, F, G) は横斷面上に全く秩序なく散在するを常とす，做々の脈管束 は, 䇥管部を根蕪周緣の方向に, 脈管部を中心の方向に存せる側立性脈管束にして, 屢々原木部 を共有し，之ょり 2 乃至數方向に放射狀に發達せるものあり(Fig. $3: \mathrm{F}, \mathrm{G})$ ，又側面に於いて 癒合せるものあり(Fig. $3: \mathrm{E})$. 脈管”束の周圍は一般柔細胞より直徑小にして，木化反應を呈す る細胞に依りて通常完全に圍匝せらる, 是所謂脈管束鞘 (Fig. 3: Gbs) なれども往く篩管部の 外方には之を認めざる事あり (Fig. 3:C), 又斷續して存在する事あり(Fig. 3:D, E, F), 又厚 


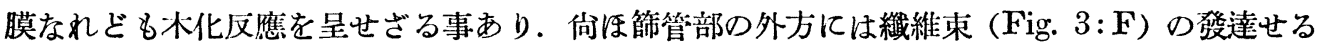
事稀ならず．然れども往々實體組織の外邊に嵌在する脈管束は脈管部のみより構成せらる(Fig.

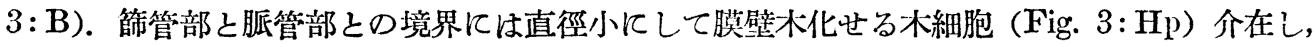
通常本坦なれども，脈管部が凹面をなす事あり，又細胞が穊管部中に突入し甚だしきは之を 左右に 2 分せるあり．脈管部は淡黄色を呈し光線を属折し强き木化反應を表す，原木部の脈管 は密に肥厚せる螺旋紋 (Fig. 3:Sgf, Fig. 4:Aの Sgf) なり, 之に次いで斷面多角形を呈し 口徑小なる擬脈管 (Fig. 3: Htr)，及び之より直徑大なる脈管 (Fig. 3:Hgf) あり，擬脈管の 孔紋 (Fig. 4:A の Htr) はレンズ形又は秒多角形なれども, 脈管の孔紋 (Fig. 4:A の Hgf)

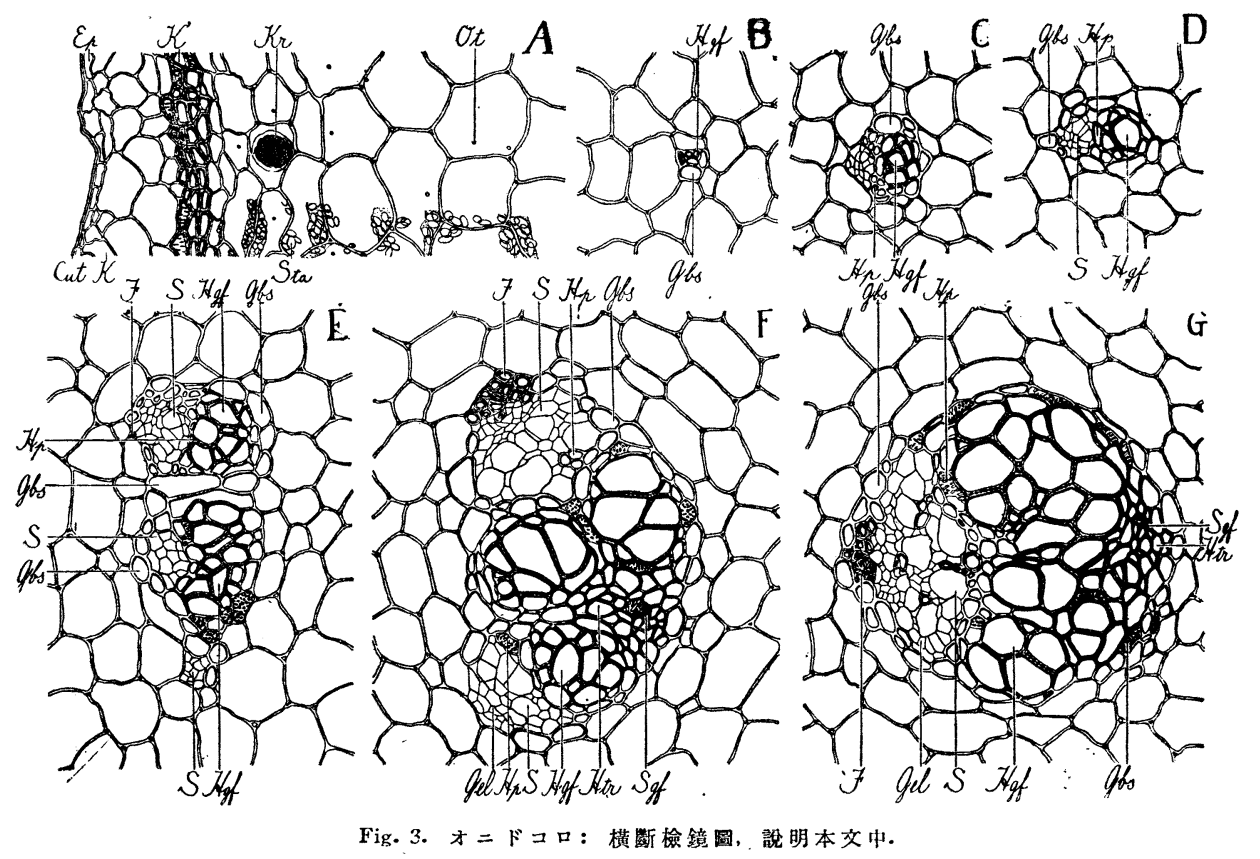

は小形にして，上下縱橫に稍規則正しく密に配列せるため著しく多角性なり。木細胞 (Fig. 4 : A の Hp）は縱斷面にて檢すれば，少しく長軸に延長し稍大なる孔玟柾に存在し，其隔壁は多 少又は著しく傾科せり．穊管部は殆んど無色なる細胞より成り，篩管(Fig. 3:S, Fig. 4:A の S) は稍大形にして, 通常橫隔壁及び縱壁に篩板を有し, 或者にはカルス板を認め, 或者には之 を認めす.＼cjkstart件存細胞 (Fig. 3: Gel, Fig. 4:A の Gel) は直徑篩管より遙に小なり. 脈管束鞘 (Fig. 4:A の Gbs)を形成せる柔細胞は, 縱斷面にて檢すれば, 隔壁多少傾科し細微なる孔斑 を其有す. 纎維(Fig. 4:A の F) は口徑小にして强く木化し, 裂隙狀の斜孔紋を佳し, 其兩端 は銃尖なり。

內容物 澱粉粒. (Fig. 3: Sta, Fig. 4:B) は實體組織中に汎く充盈すれども外邊には稍少量 
なり．其形狀球圓形，卵圓形梆圓形の單粒又は通常 2 䇢，稀に 3-5 箇よりなる複合粒にして

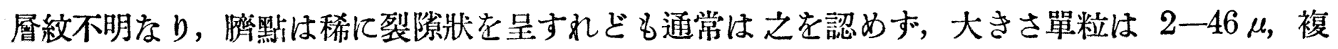
合粒ほ $12-26 \mu$ にして, 外邊の柔細胞中に含有せらるる澱粉粒は小形にして $12 \mu$ を越えす 通常 $7 \mu$ なれども, 內部の實體組織中に充填せるものは $10-46 \mu$ なり, 繊維, 木細胞中には 主として球圓形にして $2-19 \mu$ を算する澱粉粒包藏せらる. 市販生䒚中に充盈せる澱粉粒は糊 化せり, 油滴 (Fig. $3: \mathrm{Ot}$ ) は $5 \mu$ 內外にして實體組織中に散在し, 淡黄色, 球圓形にして光 線を屈折す，又主として外邊の承細胞中に塊狀をなせる黄色の內容物すりて澱粉粒を被包す，
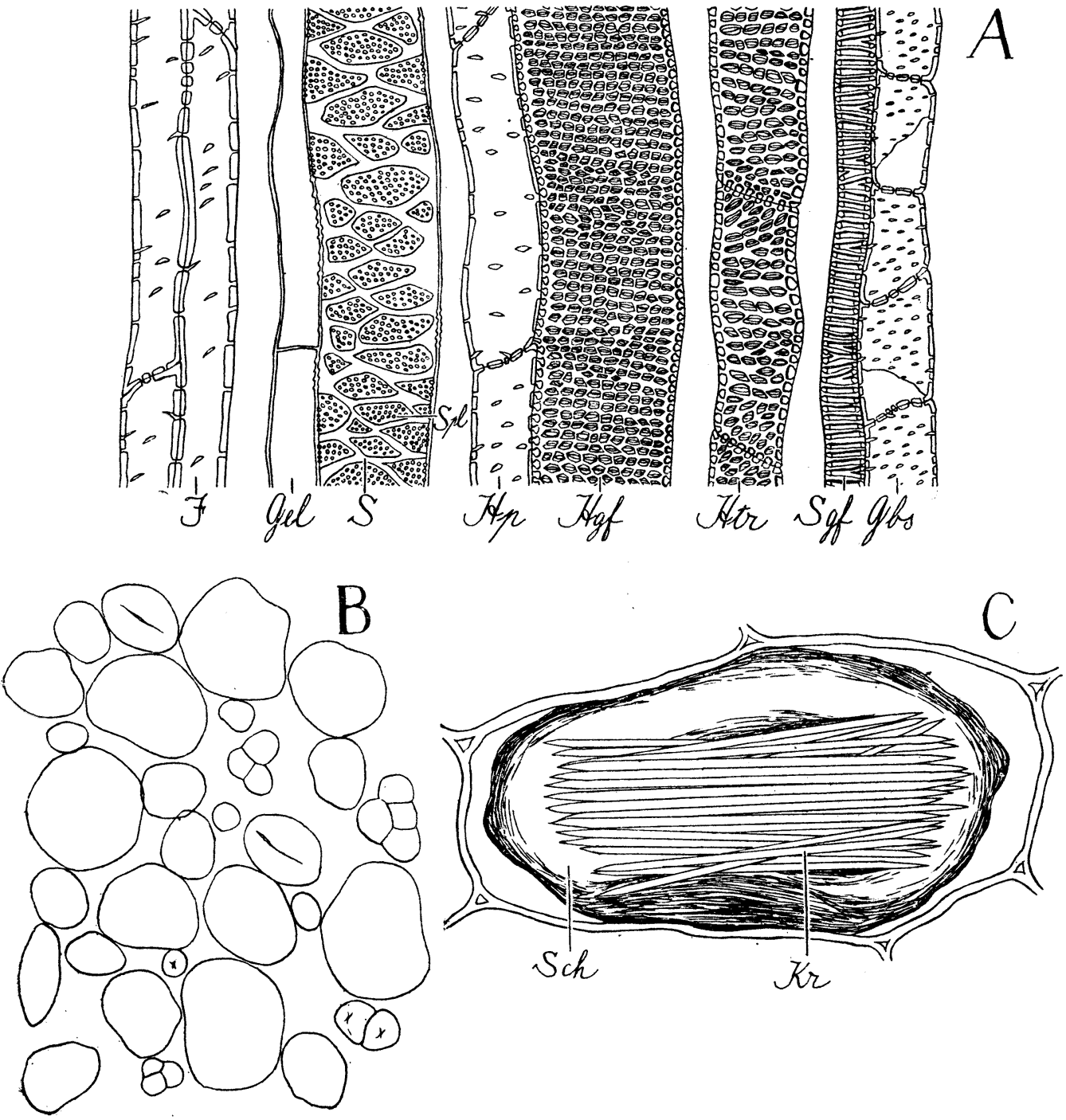

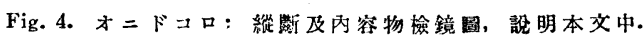


サポニンの反應は特にての部に顯著なり，郎ちアルコールと浱硫酸の同容混和液にて加溫せる 切片は赤紫色を呈し, 又 1 書夜水酸化バリウムの飽和液に浸漬せる切片を消石灰の溶液にて充 分洗滌し，10\%クロム酸カリ液を注㞦し檢鏡するに，クロム酸バリウムの結晶を檢出するを得. 葆酸石灰の束針晶（Fig. 3: Kr, Fig. 4:C の Kr）は主として實體組織の外方にして一般柔細 胞より稍大形なる秉細胞中に橫徑的に或は長軸に沿ひて存在し, 束幅 $26-62 \mu$ なり, 份ほ周 圍に粘液 (Fig. 4:C の Sch) ありて之を圍繞す,ての粘液はコンゴーロート．コラリン，ヨード グリセリンに夫ณ染色するラフィーデン粘液なり．佾はホルマリン液浸榅本にて秉細胞中に淡 黃色顆粒㸛の塊狀物の沈着せし老認めたり。

ヒメドコロ Dioscorea tenuipes Franch. et Sav.

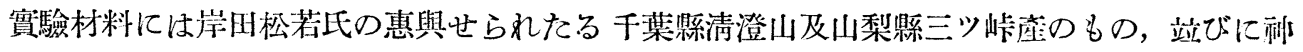
奈川縣神武寺, 同縣大山, 同縣登戶，靜岡䅫天城山に於いて自ら探集せる根茲老乾燥したるも の及びホルマリンに浸漬したるものを棜ひたり。

既に總論に於いて詳記せし如 く本品とオニドコロの根蕉とは 外觀的 (Fig. 5: A, B) 飞辫别 するを可とし，下に摘記する內 部構造上の美異は常套的のもの に非ざるため，之等に低りて网 種を確然と區别する事は困難な b.

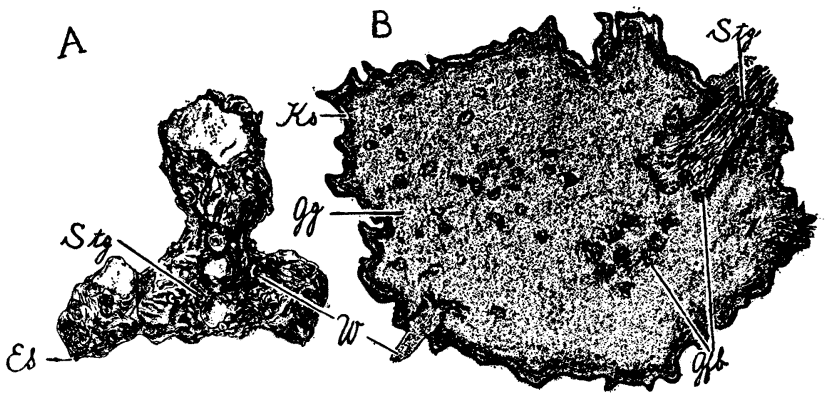

Fig. 5. ヒメドコロ：A は全形國×2/3. B は横斷面ルーペ圖.

厚膜及薄膜性网枹細胞其，オニドコロの夫れに 比して横徑に延長し，且つ厚膜性枹細胞の膜 壁は稍菲薄なるを常とす。又實體組織の柔細胞にして，外邊より5-6 層稀に 10 數層のもの はオニドコロに於ける如く横徑に延長すれども, 之より內部に續く凡そ 10 居位の乘細胞は往 ふ牛徑性方向に稍延長せるもの西り，佾ほ實體組織中に 石核細胞の出現する事は絶えてなし. 脈管束はオニドコ口の夫れより少數且小形にして，穊管部の外側にある纎維束の發達せるもの 稀なり.內容物としては澱粉粒は, 單粒は 2-60 根莖中に立滿せるものより稍大形なり, 佾ほ實體組織の外邊に, 屡々不定形にして紅紫色を呈 するアントチアンの塊の含有せらるる事は，オニドコロに視ざる所なり，

草䰻及タチドコロ Dioscorea gracillima Miq.

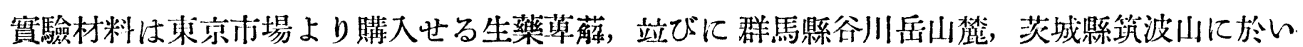
て自ら探集せる根䒚を乾燥したるもの及ホルマリンに浸漬したるものに低れり。

形狀 生燕草薢 (Fig. 6) は通常長さ約 8-12 cm に切斷し，徑約 $1-3 \mathrm{~cm}$ なり. 外面は赤褐 $-4^{8}-$ 
色, 黄褐色乃至淡黑褐色を呈し, 往ヶ䰅根燒却のため 黑色の燒痕を認む, 通常淺くして比較的

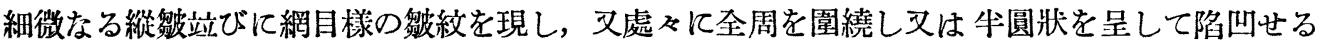

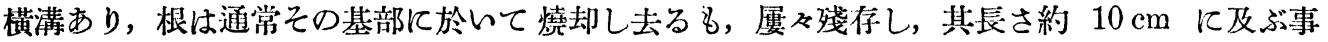
あり，何れも外部は根般の基部にわづかに視るのみにして內部のみ挺出し，其外面は淡黄裨色 を呈し强鞓且滑澤にして 細根の殘基を認 め，先端は燒却のため黑色を呈す，根莖の 上面には隆起極めて多く, 其基部に鱗片樣 のもの存在し，數筐の圓形或は楕圓形をな し多くは淡明なる洀痕ありて地上莖の殘基 (Fig. 6:Stg)乙の上着生す，地上莖は帶 白褐色又は㣴褐色にして縱線を表し，通常 除去すれども稀に殘存し長さ約 $5 \mathrm{~cm}$ に洼 す，土芽 (Fig. 6: Es) は黑褐色にして網 日状に皺縮せり。资硬く, 破折面は帶黄白 色にして緻密なり。香芲なく，味少しく若 L.

構造 ルーペを以つて横斷面を檢するに,

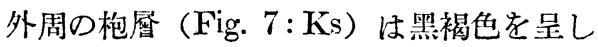
菲薄なり，實體組織は極めて膨大にして帶 黄白色を呈し，淡黄色の脈管束は不規則に 散在し，科縱斷面として出現する事稀なら ず，又分岐部，地上亚 (Fig. 7: Stg) 及び 根 (Fig. $7: W$ )の分出點に於いては總へてて 縱斷面又は科縱斷面々して現はる.

顯微鏡下に檢視するに，上皮（Fig. 8： $\mathrm{Ep}$ ）は小形にして淡黃色の細胞よりなり 往々橫徑に延長す，外面に表皮膜 (Fig. 8： Cut）を被むり，孔斑を侍すれども水反 應なく枹化反應を呈し，枹細胞との間に胞

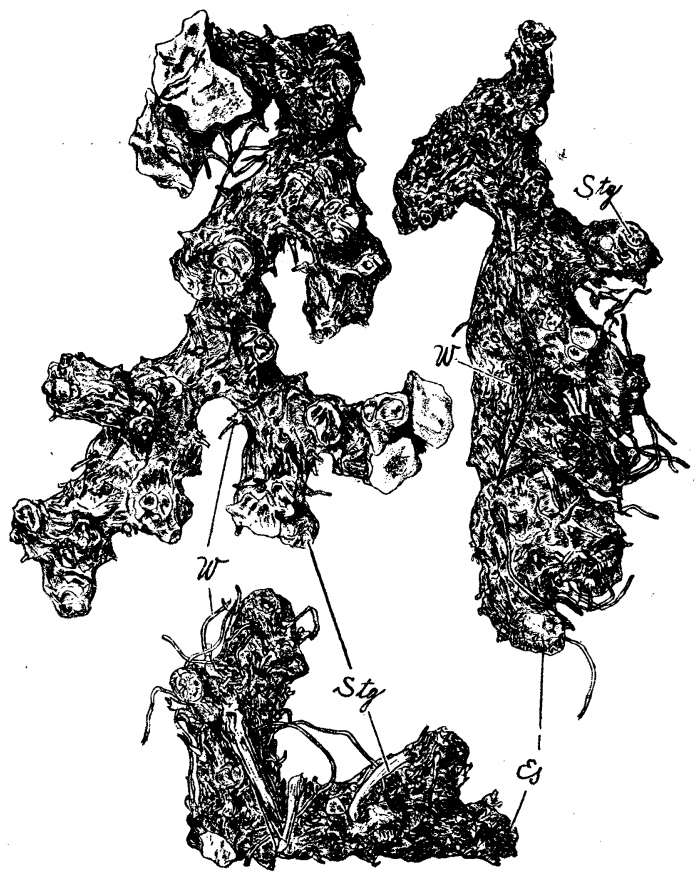

Fig. 6 タチドコロを原植物 とせる市場品の全形圖 $\times 2 / 3$.

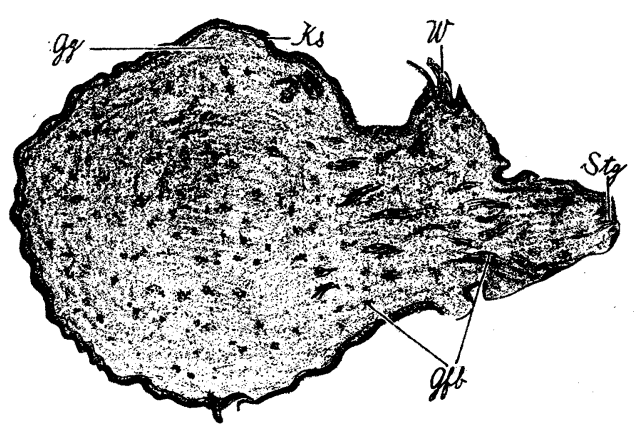

Fig. 7. タチドコロを原植物とせる市昜品の横斷面ルーペ圆.

間を表はす. 薄壁性枹層 (Fig. 8: K) は 1-5 層の略等徑性なる枹細胞よりなり，其膜壁は淡

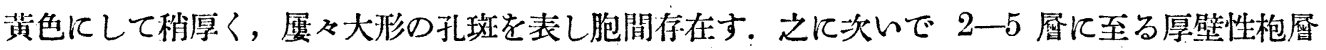

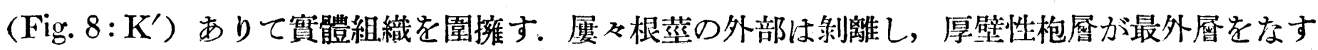


を視る. 其各枹細胞は小形にして橫徑に延長し且牛徑性方向に規則正しく配列すれども，外邊 のものは略等徑性なり，其膜壁は極めて厚く，顯著なる孔斑站びに層紋を表し，木化反應，枹 化反應は共に初生膜層に於して特に强し，實體組織の外邊には略等徑性又は觸線性方向に延長 せる淡黃色を呈し稍厚膜にして粗大なる孔斑を具有する柔細胞 6-7 詹存在し，之より內方の乘 細胞は略等徑性にして不規則に配列し，其膜壁は厚く淡黃色を呈し孔斑を其へ，何れも第二期膜 層のみツェルローゼ反應を呈し, 又初生膜層のみ秒弱き木化反應を表す, 又との部柔細胞にし て外邊に存する凡そ 10 㸴の細胞は著しく牛徑性に延長する事稀ならず。脈管束は實體組織中

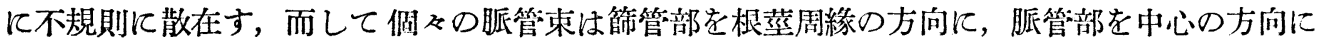
配置せる側立性脈管束をれども，內部には通常 2-3 簡の脈管束相反對せる位置を取り原木部 を共有し，又は其側面に於いて癒合せるもの等存在す，倘ほ屡々內方には兩管性の構造を有す

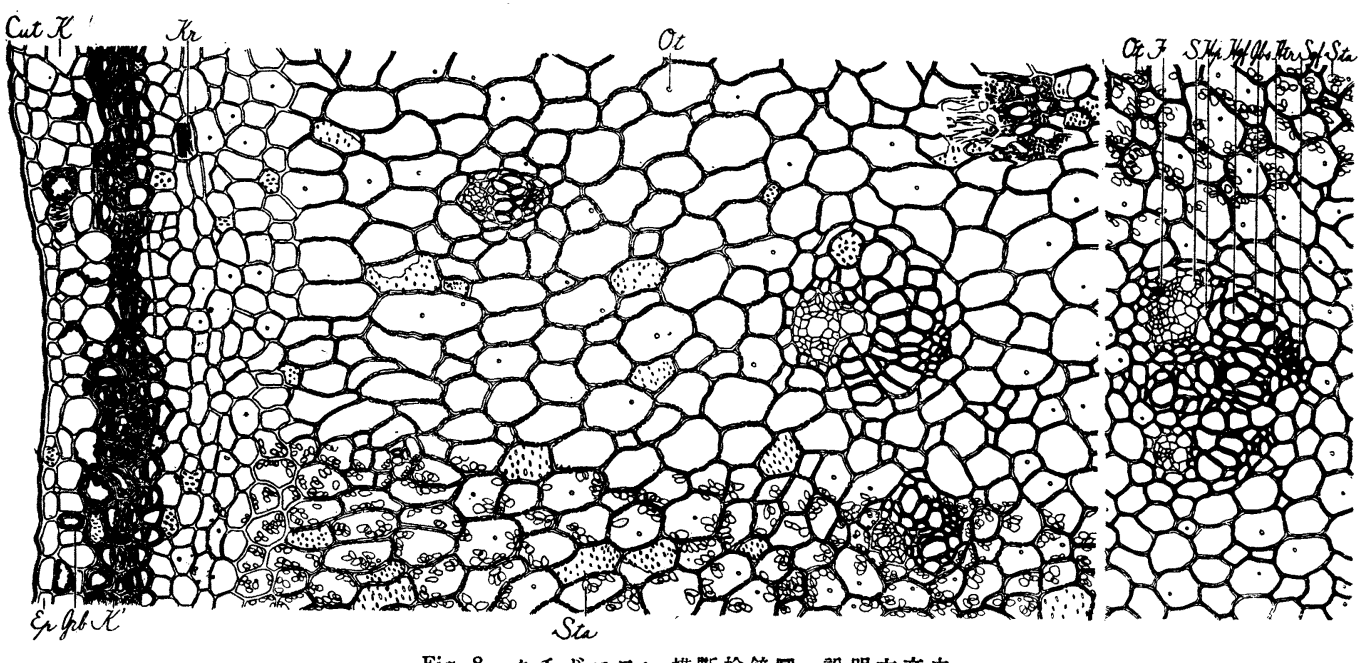

Fig. 8. タチドコロ: 横斷检鏡圆, 詀明本文中.

るものを交ふ. 眽管束の周圍には一般柔細胞より直徑小にして，木化反應を呈する細胞すりて

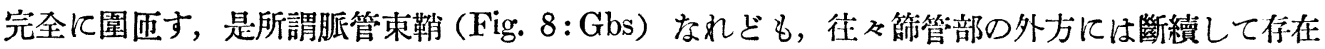

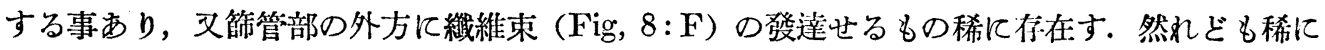
根蕉の外邊に存する脈管束は 脈管部のみを以つて構成せらるる事すり, 脈管部之笠管部之の接 面には直徑小にして稍强き杫化反應を呈する木細胞（Fig. 8: Hp）介在し脈管部が凹面をなす を常とすれども，屡く木細胞が穊管部內に突入せるものあり，又本坦なるものあれども稀なり. 脈管部は大部分淡黃色にして光線を屈折し强き木化反應を呈し，上下に稍規則正しく配列せる 多角性有緗孔紋を有する脈管 (Fig. 8: Hgf, Fig. 9:A の Hgf), 及口徑前者より小且短くし て，楕圓形の有緣孔紋を踈に表す擬脈管（Fig. 8: Htr, Fig. 9:A の Htr) にして，原木部の 脈管は常に蝃旋紋脈管 (Fig. 8: Sgf, Fig. 9:A の Sgf) なれども其數少し. 木細胞 (Fig. 8: 
Hp, Fig, 9:A の Hp）は縱斷面にて檢すれば，長軸の方向に延長し粗大なる孔斑を具有す. 篩管部は殆んど無色の細胞よりなり，稍厚膜にして初生膜層は往ふ弱き木化反應を呈す．節管 (Fig. 9:A の S) は橫隔壁站びに縱壁に篩板を有し，カルス板を認むる事稀をらず. 脈管束鞘 (Fig. $9: \mathrm{A} の \mathrm{Gbs)}$ を形成する柔細胞は縱斷面にては隔壁は多少又は著しく傾斜し稍大なる孔

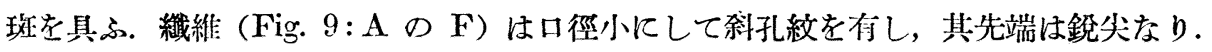

A

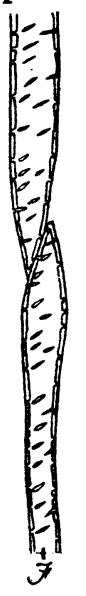

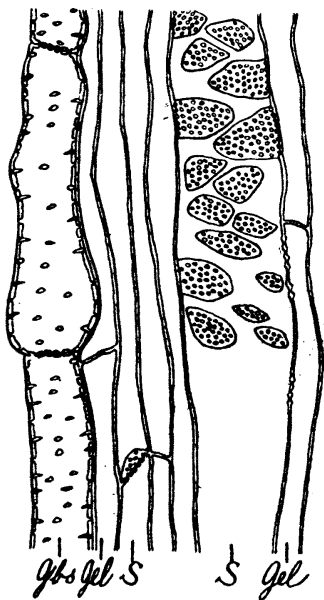

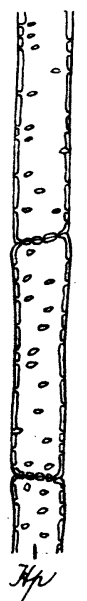

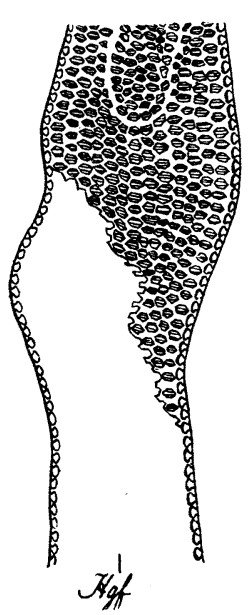

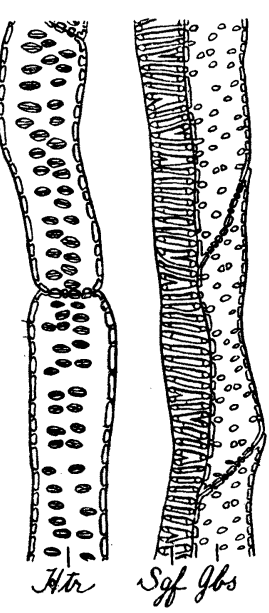

B

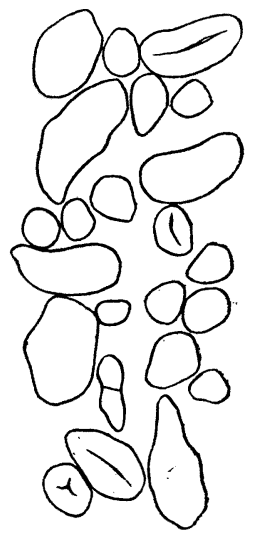

內容物 潎粉粒 (Fig. 8: Sta, Fig. 9:B) は實體組織中に汎く存在すれども, 外邊の觸線性方 向に延長せる秉細胞中には小形なるもの少量包付せらる, 又纖維, 水細胞中に包藏せらるるもの は主として球圓形なり, その他の部位に存する澱粉粒は牛月形, 球圓形又は楕圓形にして, 胼點 の明膫なる者あり，然らざるものあり，中心性又は偏心性にして漛紋明ならず，單粒又は 2 箇よ

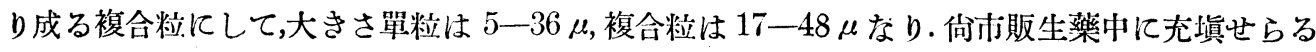
る澱粉粒は種々の程度に糊化せり. 油滴(Fig. 8:Ot)は $5 \mu$ 內外にして, 實體組織中に散在す.又 實體組織は汌くサボニンの反應を表す. 葆酸石灰の束針晶(Fig. $8: \mathrm{Kr})$ は外邊の觸線性に延長せ

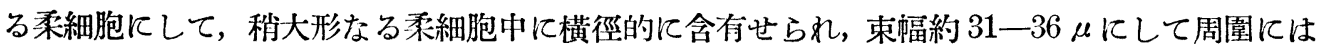
粘液を認めず. タンニン質 (Fig. 8:Grb) は上皮及薄壁性枹細胞中に顆粒をなして存在し, 稀に 厚壁性枹細胞中にも出現す. 穊管竝びに伴存細胞中には蛋白質の反應を呈する淡黃色の不定形 の團塊存在す. 尚压ホルマリン液浸標本の實體組織中には淡溭色の塊狀物の沈着せるを認めたり.

キクバドコロ Dioscorea septemloba Thunb.

實驗材料には岸田松若氏の惠與になる埼玉縣伊豆摔產のもの, 站びに神㴎川縣程ヶ谷, 荻城 縣筑波山及び群馬縣谷川岳山麓にて自ら探集したる根兴の乾燥品站びにホルマリン液浸標本を 供用せり。 
總論に於いて概略記せしが如く.本品とタチドコロの根茎とは外觀的 (Fig. 10:A，B) には辨 别する事困難にして，唯本品が タチドコロの根莖に比して，節間稍延長し，根䓰の上方に向人 る隆起部にして地上蓋の附着 すべき部分少く，又その破折 面は多くは黄色を呈する事以 外には兩者の間には差異を認 めざれども，顯微鏡によりて は制然と類別する事を得．今 內部構造上の差異のみを列記 すれば, 薄壁性枹檿(Fig. 11：

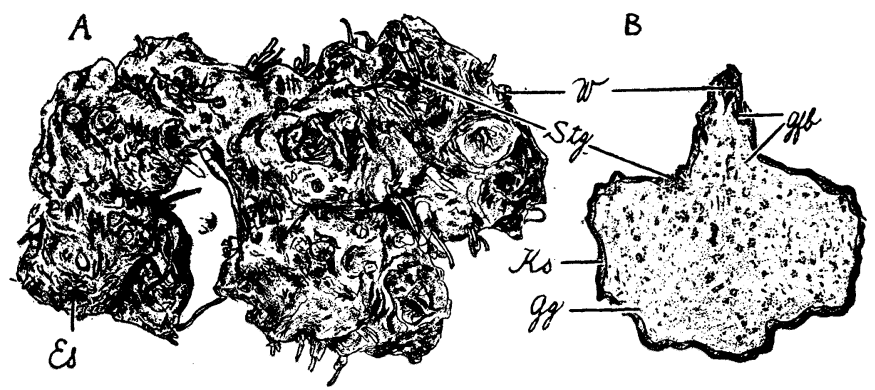

Fig. 10. キクバドコロ：A は全形圆 $\times 2 / 3 . \mathrm{B}$ は橫斷面ルーペ圆.

AのK)はタチドコロの夫れ より多層にして往々 8 糜江至 る事市り，又厚壁性枹層(Fig. 11:Aの K') は通常 1-2 層 存在し, タチドコロの夫れに 比し薄膜にして略等徑性且不 整の配列をなす，更に之より 內方に續く觸線性方向に延長 せる柔組織の最內層の $1-2$ 層のものは稀に膜壁肥厚し石 核細胞となる，又タチドコロに於いては柔細胞は總べてその第二期膜層はツェルローゼ反應を 呈すれども，本品にはこの性狀なく全部木化す，澱粉粒はその外形は 異らざれどもタチドコロ

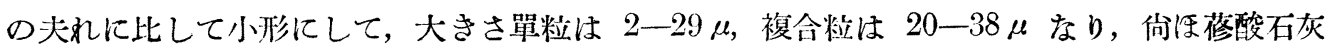

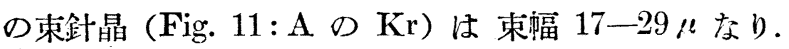

カヘデドコロ Dioscorea quinqueloba Thumb.

實驗材料は鹿兒岛才內及び櫻島，長崎縣稻佐山，份賀縣多良猚に於いて自ら採集せる根蒙を 乾燥したるもの，端びにホルマリンに浸漬したるものを䏳てたり。

形狀 本品の外觀はタチドコロ及びキクバドコロに類するも，彼等の如く分岐する事少く， 粗大なる縱袚を表し，皮部は鱗片狀に附着す（Fig. 12）。

構造 剖見するに，上皮は稀に殘存するのみにして，通常薄壁性枹曆(Fig. 11:Bの K) 之に 代る. 其枹細胞は大約 9 層にして，膜壁は黄褐色韭薄にして波濤狀を呈し，孔斑を具有し胞間 を表し，枹化反應を呈すれども，木化反應を表さず．次いで通常 8 層なるも多きは 20 層に及 
ぶ略等徑性にして不整に配列せる枹細胞を以つて構成せらるる厚壁性枹層 (Fig. 11:B の K') あり，該枹細胞の膜壁は餘り厚膜ならずして孔斑を有し胞間存在せず，枹化反應は初生膜層に

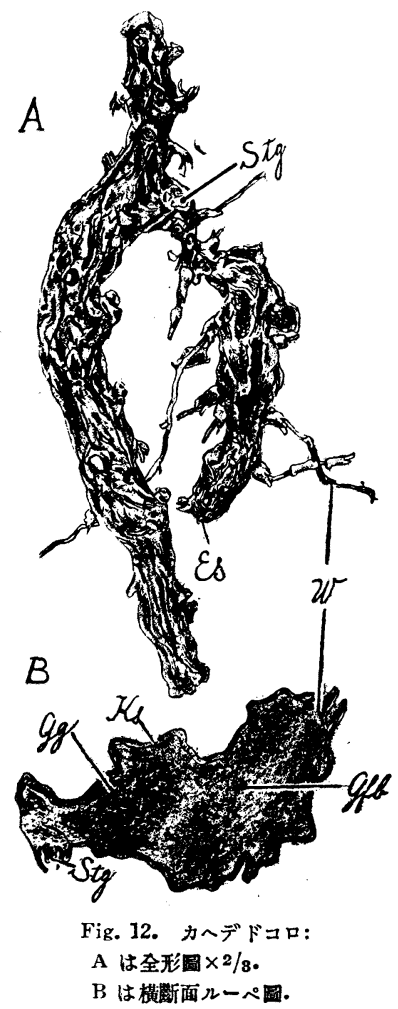
於いて特に强く, 木化反應は初生膜殿のみに現る。實體組織は 大小不同，不整の配列をなせる柔細胞よりなり，外邊のものは 觸線性方向に稍延長せり，其膜壁は稍厚く孔玟を有し，ツェル ローゼ反應を呈すれども，初生膜層のみは化反應を表す，縱 斷面に於いて內方の多のは長軸の方向に延長し先端少しく尖れ り. 脈管束の配列の狀態站びに之を構成せる要素の種類, 性狀, 形狀及び配置の样式等，オニドコロの夫れ之撰ぶ所なし.

內容物 澱粉粒(Fig. 11:B D Sta) は柔細胞中に少量宛包藏 せられ，單粒又は複合粒にして，共形槠圓形又は球圓形にして， 著明なる馬蹄形又は裂吵㹜を呈する偏心性脐點を具有し，層紋 は不明なり，而して大きさ單粒は $3-43 \mu$, 複合粒は $19-31 \mu$ なり, 脈管束鞘, 水細胞站びに纖維中に充塡せるものは主とし て球圓形なる單粒にして，其大きさ5-22 11: B の Ot）は $5 \mu$ 內外にして球圓形をなし柔細胞中に沉く 合有せらる.サポニンの反應子亦柔組織中に現る．葆酸石灰の 束針晶 (Fig. 11：Bの Kr) は稍大形となれる柔細胞中に通常 長軸に沿ひて粘液中に嵌入せり，乙の粘液も亦ラフィーデン粘

液にして，ヨードグリセリン，コラリン，コンゴーロートにて 染色す.タンニン質は薄壁性枹層中に稀に顆粒状をなして存在す，佾注ルマリン液浸標本の 切碑を檢するに秉細胞中に淡黄色にして顆粒狀を呈する物質存在せり。

草蔽及ウチハドコロ Dioscorea nipponica Makino

賽驗材料は東京市場に於ける生藥草薢, 站びに 群馬縣谷川岳山麓に於いて自ら探集せる根莖 の乾燥せしもの及びホルマリン浸とせしものに依れり.

形狀 生藥草薢(Fig. 13:

A) は通常長さ約 $8-9 \mathrm{~cm}$ に切斷し, 徑約 $0.6-0.9 \mathrm{~cm}$ なり，棒狀にして外面赤褐 色乃至黑褐色を呈し, 略平 行せる精粗種々なる縱皱を 有す, 處々に地上莝 (Fig.

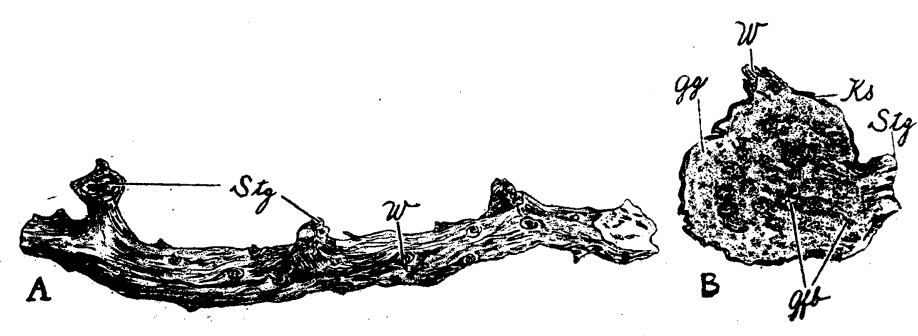

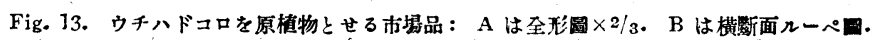




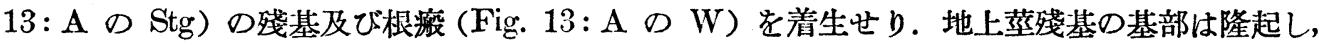
立に數䇢の小皿狀をなせる莖痕あり，其の凹面は 赤褐色又は黃褐色にして脈管に因る數第の突 起輪列す，根版は根茎長軸の方向に稍長き棈圓形の凹寉にして，之より通常約 $0.1 \mathrm{~cm}$ の小笑 起笑出せり，之根の內部の殘存せるものにして燒痕のため先端黑色を呈す. 破折面は淡黄白色 㮐粗薐にして殆んど平坦なり。香氣なく，味稍涉苦なり.

構造 ルーペに依りて横斷面を覞ふに，枹層（Fig. 13:Bの Ks）は黑褐色にして處々涂離 せり，內部 (Fig. 13:B の Gg) は淡黄白色又は帶褐黄色にして，黄色の脈管束 (Fig. 13:B の Gfb) 均等に分布し, 脈管部を明視するを得, 縱斷面にて脈管束は長軸に平行して存在する 故, 地上蒙 (Fig. 13:B の Stg) 及び根 (Fig. 13:BのW) の分出部に於いてのみ縱斷面又 は科縱斷面として出現し，其周圍は一般に暗褐色を呈す。

顯微鏡を以つて檢するに，上皮は稀に 壓縮せら れて殘有するのみにして，橫徑に延長し不規則に 配列せる 3-6 層の枹細胞よりなる薄壁性枹層 (Fig. 14:K) 之に代る，其膜壁黄褐色にして稍厚 く, 孔斑端びに橫梁 (Fig. 14:Qb) を具有し胞間 を現す，枹化反應は初生膜尿に於いて特に强し， 又屡々毛革（Fig. 14：H）索外部に突出するも其 基部は往及深く枹細胞中に潛入す，該毛革は根毛 樣の形態を具へズダン III にて染色し，往々分岐 し稀に螺旋狀の肥厚をなす(Fig. 15). 更に其の内 部には 1-3 層の厚壁性枹層 (Fig. 14: $\mathrm{K}^{\prime}$ ) 西りて 實體組織を圍む．各枹細胞は略等徑性にして不規 則に配列し胞間を具有し，膜壁淡黄色にして左程 厚膜ならず，孔斑を有し，木化反應，枹化反應は 共に初生膜曆に於いて特に强し，厚壁性枹層と實 體組織との境界面は往飞枹生組織㥞の配列をなし， 之より內方に續く數層の柔細胞は薄膜にして孔斑 を有せず，ツェルローゼ反應を現し，胞間を有し
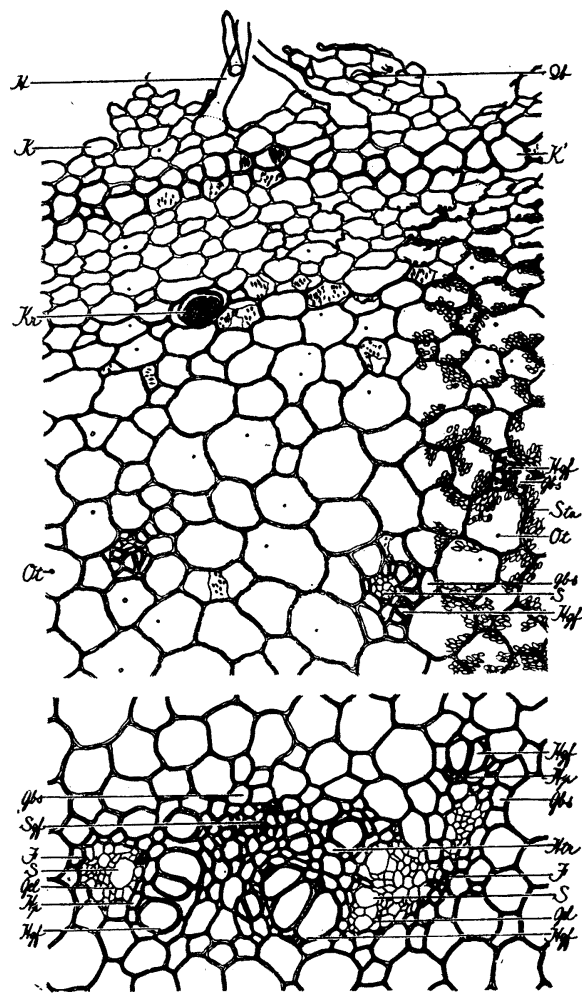

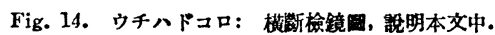
橫徑に延長す，ての部には脈管束を認めず. 次いで略等徑性の柔細胞ありて之に連なる，其膜 壁は極めて厚く孔斑を有し第二期膜層のみツェルローゼ反應を呈し, 初生膜層のみ木化反應を 表す, 縱斷面に於いては稍長軸に延長し先端少しく尖れり. 脈管束は總へて根莖外周の方向に 節管部の存在する側立性脈管束なれども，內部には通常 2-3 箅の脈管束相反する位置を取り, 
原木部を共有し, 又は脈管束の側面に於いて癒合せるものを混在す. 脈管束の周圍には一般柔細 胞より口徑小にして稍强き木化反應を呈する壓扁せられたる細胞(Fig. $14:$ Gbs)存在す, 是所謂

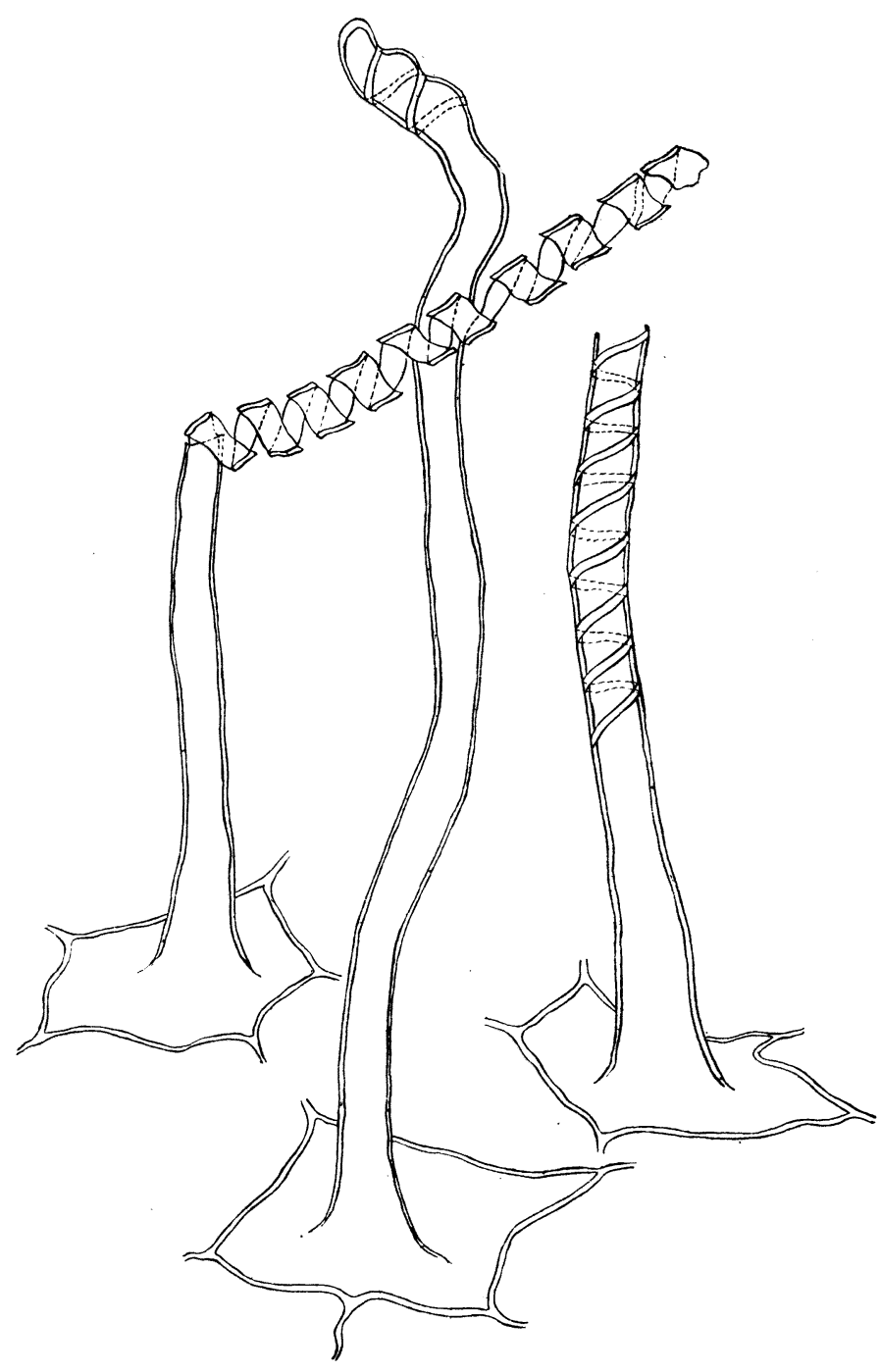

Fig. 15. ウチハドコロ：根蕉の毛苜, 訜明本文中. 脈管束鞘なり，份压屡々篩 管部の外方汇纖維束 (Fig. $14:$ F) の發澾せる老視る, 然れども根蒙の外邊には脈 管部のみよりなる脈管束嵌 在す、胍管部と穊管部との 接界面には直徑小にして秒 强き木化反應を呈する木細

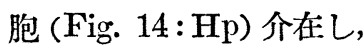
其接界面は平坦なるを常と すれども，脈管部が凹面を なす事あり, 又木細胞が篩 管部內に䓡入し，甚だしき は之を左右に 2 分せるあ り. 脈管部は淡黄色を呈し 光線を屈折し强き木化反應 あり，其の多くは上下，縱 橫に稍規則正しく密に配列 せる多角形の府緗孔紋脈管 (Fig. $16: \mathrm{Hgf}$ )及び楕圓形 又稍多角形にして，不整 且つ柾に配列せる有緣孔紋 を有する擬脈管 (Fig. 16: Htr)にして，擬脈管は脈管 に比し口徑小にして短し,

佾ほ極めて稀に網紋脈管:(Fig. 16:Ngf) 混在す。原木部の脈管は常に螺旋紋脈管(Fig. 16: Sgf) なり.木細胞 (Fig. 16:Hp) は縱斷面にてその隔壁稍傾斜すれどもわづかに長軸の方向に延長 するのみ. 節管部は殆んど無色の細胞よりなり稍厚膜にして, 稀に末化反應を呈する部分を混有 する事あり,穊管(Fig. 16:S)はその口徑稍大にてして隔壁及び縱壁に笠板を有し，或者にはカ ルス板を認め, 或者には之を認めず. 伴存細胞 (Fig. 16:Gel) は直徑穊管より遙に小なり。脈 
管束鞘(Fig. 16: Gbs) を形成せる柔細胞は, 縱斷面にて一般柔細胞とその形狀大差なけれども, 口徑小にしてその隔壁稍傾科する事により判別せらる. 織維 (Fig. 16:F) は相集りて束狀とな り穊管部外方に存在し，口徑小にして强く木化し，縱斷面に於いて圓形又は棈圓形の單孔斑を 現し，其の兩端は尖銃なり。
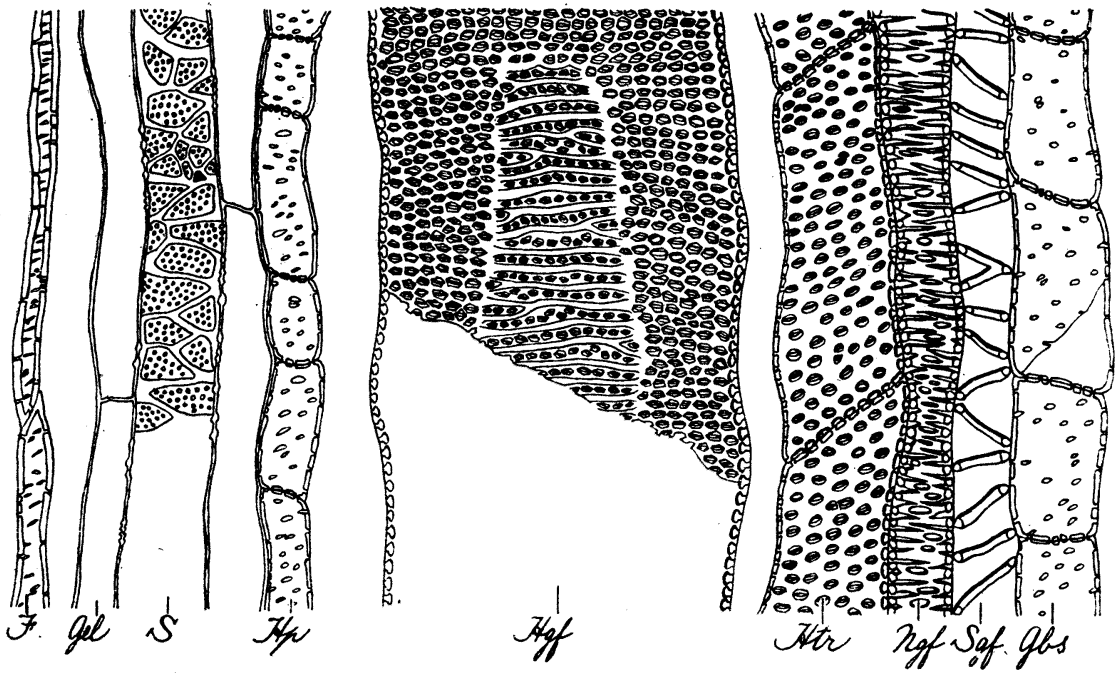

Fig. 16. ウチハドコロ：䝪斷檢鏡圆, 說明本交中.

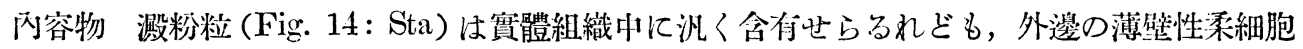

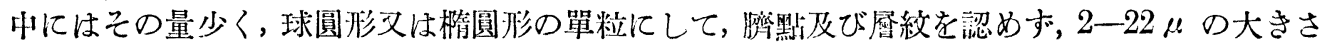
を有す, 又木細胞, 脈管束䩗, 織維中に存在するものは, 主として小形, 球圓形なり。倘ほ市 貶生燕中に包含せらるるものは通常糊化せり．油滴 (Fig. 14: Ot) は $5 \mu$ 內外にして沉く實體 組織中に散在す。サポニンの反應は實體組織の外透に於いて特に强く,グリセリンを媒介とし て檢鏡するに淡黄色の塊として認むべし. 悠酸石灰の束針晶 (Fig. 14: Kr) は等徑性なる厚膜 性柔細胞の外邊の稍大なる細胞中に存在し束幅 22 - $72 \mu$ にして周圍には粘液ありて之を包有

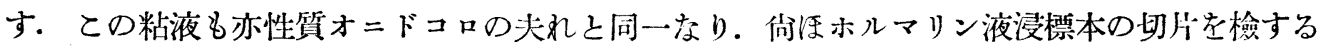
に柔細胞中に淡黃色顆粒狀の塊状物存在す.

草㗱及びニガガシュウ Dioscorea bulbifera L. f. spontanea (Makino)

福岡术の樂舖に於いて自ら購入せる草触及び緒方正資氏の惠與せられたる沖繩縣西表島產の

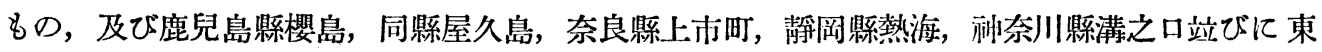
京府下五日市町にて自ら探集せる塊镸の乾燥品及びホルマリン液浸標本を用ひて鏡檢したり。

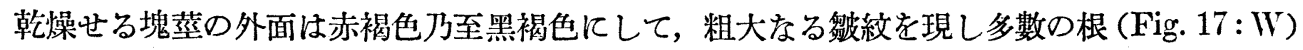
を附著すれども，塊蕪の底部（Fig. $17: B$ ) は收縮して大なる凹洼となり少數の根を着生せるを 
視る，刃上部 (Fig. 17:A) は著しく隆起して地上蓙(Fig. 17:A の Stg)に連り，稍太き根を 疎に附着し，又その橫面には前年の地上曼の附着せし瘢痕(Fig. 17：A の Stg’)を認む。向ほ

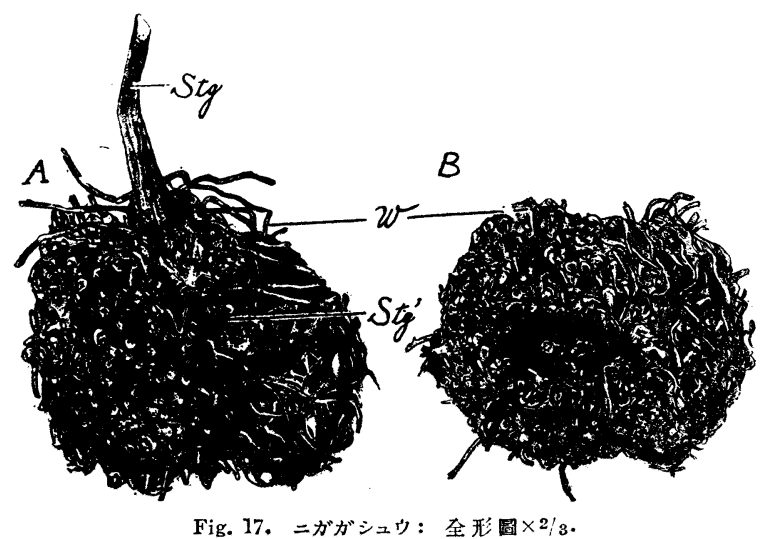

福阔方にて購大せる市場品は砂中に 眝へありし故，東京にて移植し二ガ ガシュウなる事をたしかむるを得た b.

剖見するに, 直徑約 $2 \mathrm{~cm}$ の塊莖 に於レても既に外部は剥離し，薄壁 性枹㸴 (Fig. 18:K) の一部分殘存 するを視るのみにして，塊蕪の中部 の橫斷面に於いて，其各枹細胞は觸 線性方向に延長し不規則に配列し，

膜壁は黑褐色を呈し韭薄にして孔斑を有し，枹化反應を呈すれども，木化反應を表さず。之に 次ぐ厚壁性枹層 (Fig. 18: K') 女亦臅線性方向に著しく延長し不規則に配列せる 3-7 層の枹細 胞よりなり，其膜壁は淡黄色にして厚化し細長なる孔斑を具有し，木化反應，枹化反應は共に 初生膜層に於いて特に强し. 然れども厚膜性及薄膜性兩枹細胞共に, 上下兩部に至るに從ひ略

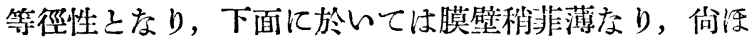
縱斷面に於いては兩枹細胞は共に略等徑性なり．實體 組織の外邊に存する 3-4 屡の柔細胞は通常臅線性方 向に延長すれども，內部に至るに從ひ漸次略等徑性の 柔組織に移行す，其の膜壁は稍厚く，或る部分はツェ ルローゼ反應のみを呈すれども，他の部分は水反應

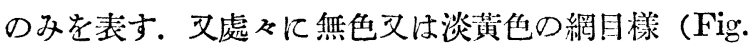
19：A）の膜質ありて澱粉粒を包圍す，乙の膜質は部 分に因り林化反應又はペクチン質の反應の何れか一方 のみを現す，脈管束は總へてて側立性脈管束にして全く 秩序なく散在し，其走向不規則なるを以つて或は橫斷 せられ，或は縱斷せられて出現す，脈管は其橫斷面稍 多角形にして，主として螺旋紋 (Fig. 19:B の Sgf)

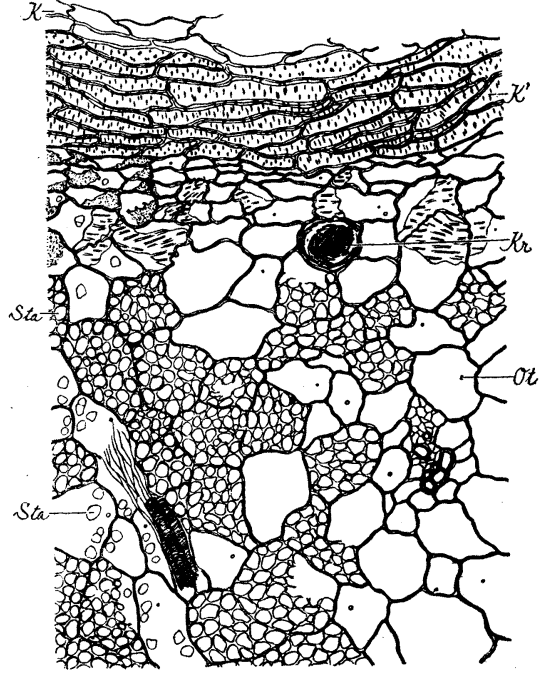

Fig.:18. ニガガシュウ：横斷檢镜圆，說明本交中。

又は環紋 (Fig. 19: B のRgf) の模桹を倠すれども，稀に階紋（Fig. 19：B の Trg）を表す， 脈管の周圍の柔細胞は一般柔細胞より少しく延長せり，又織維束を認めず，

潵粉粒 (Fig. 18: Sta, Fig. 19：C) は柔細胞中に立滿し，屢及網目樣の膜質を以つて被包せ 
られ，外邊の柔細胞中に包藏せらるるものは主として球圓形にして少量なれども，一般に其形 球圆形，楕圓形，馬蹄形等にして，通常臍點站びに層紋は不明にして，單粒又は通常 2 箇より

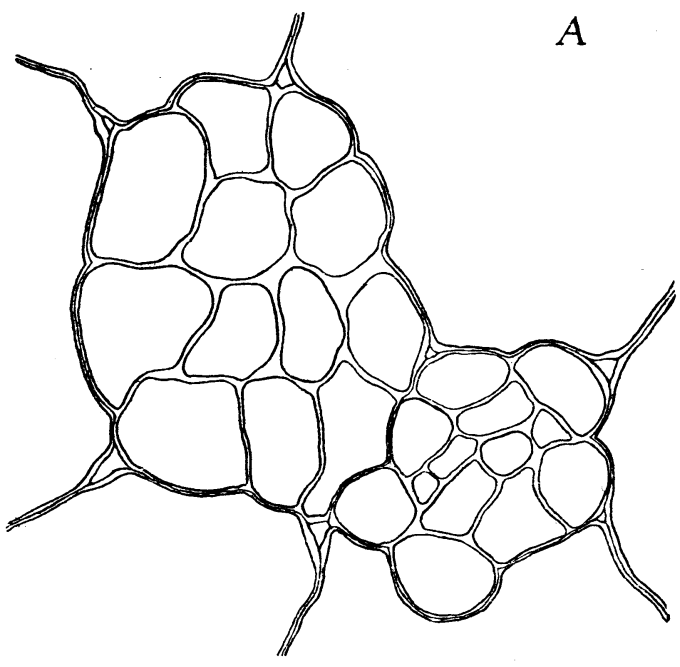

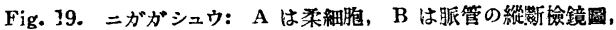

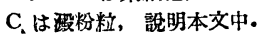

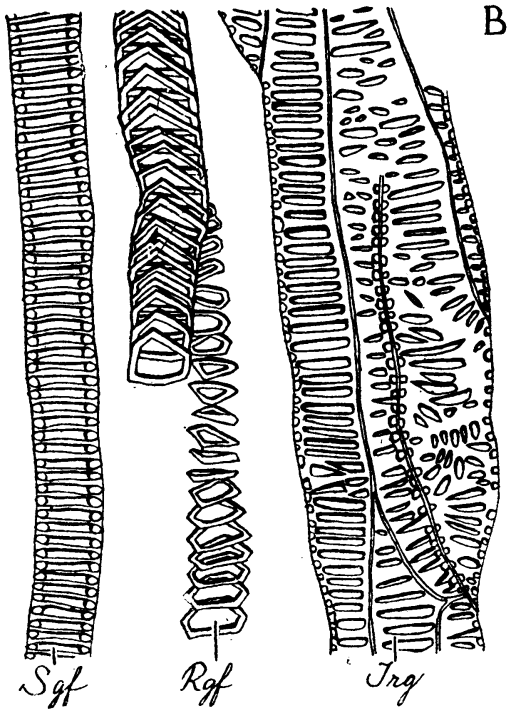

なる複合粒なり，其大きさ單粒は 2 -36 $\mu$ ，複合粒は

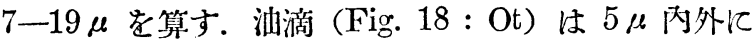
して實體組織中散在せり，又實體組織は總べてサポ ニンの反應を呈し，澱粉粒の少き外方にては淡黄色の 顆粒狀をなして存在するを視るへしし，苳酸石灰の束針 晶 (Fig. 18: Kr) は特飞實體組織の外邊沉多く存在し て，ルテニウムロート，ヨードグリセリン，コンゴー ロート，メチレンブラウに染色する粘液中に嵌在し， 縱斷面，斜縱斷面及横斷面として現る．ホルマリン液 浸標本の切片を檢するに，柔細胞中には淡黄色にして 不定形なる顆粒狀の團塊の沈着せるを認めたり。

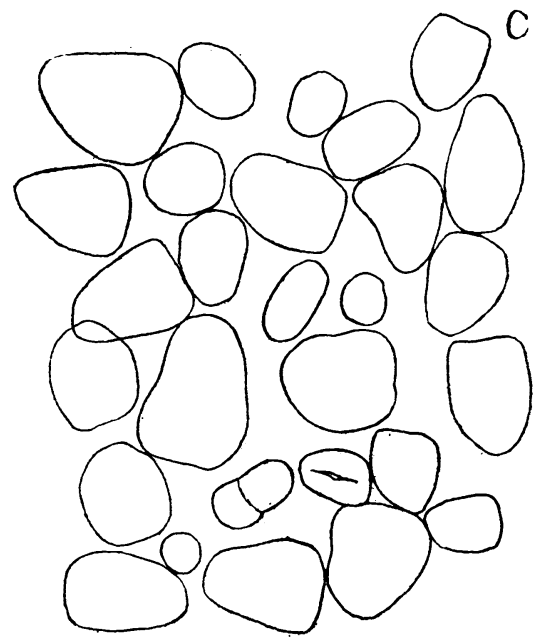

略 字 解

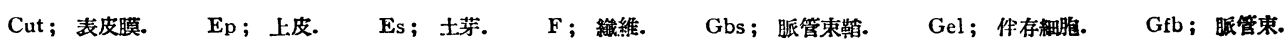

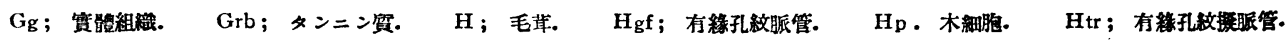

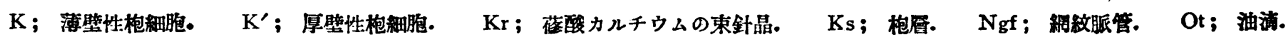

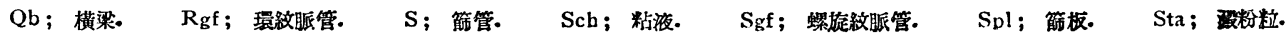

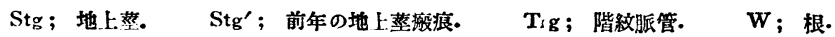

